\title{
DEVELOPMENT TRENDS IN THE NATIONAL ECONOMY SECTORS IN THE BALTIC STATES IN 2005-2015
}

\author{
Liana Supe, Inguna Jurgelane \\ Riga Technical University, Latvia \\ Liana.Supe@rtu.lv; Inguna.Jurgelane@rtu.lv
}

\begin{abstract}
The processes of globalization in the world economy have a significant impact on different processes and development in all national economy sectors. Innovations and technological development have also increased the competition between economic operators. Faster growth is also observed in service industries. The global economic downturn affected the Baltic States whose development suffered a sharp decline at the end of 2008 and in 2009. A sudden drop in the demand in export markets, as well as the decline in the demand in the domestic markets due to low purchasing power contributed to the deterioration of the economic situation in the Baltic States, particularly in the manufacturing and construction sectors. Starting from 2011, the economic indicators in the Baltic States have been growing and here the export of goods and services can be mentioned as the main contributor to the development of the economy in the Baltic States. Significant changes in the development of economic sectors started in 2013 due to Russia's economic problems. During the period 2005 - 2015, most of the value added to the overall structure of the national economy in all three Baltic States was brought by trade and manufacturing.

The aim of the research is to analyse the national economy sectors in the Baltic States during the period 2005 - 2015 in order to determine processes that affected the development of economy sectors in each of the countries, or the opposite - the recession, thus finding the most competitive sector of the national economy of the Baltic States.
\end{abstract}

Key words: national economy sectors, Baltic States, competitiveness.

\section{Introduction}

After joining the European Union in 2004, the Baltic States experienced a rapid economic growth and at the same time a sharp rise in commodity prices, which led to high inflation. In 2009, along with the economic downturn in the global economy, the Baltic States experienced a sharp decline in the national economy when the volumes of the products sold in the domestic market and the volumes of export products dropped. In early 2010, the national economy in the Baltic States gradually recovered; the most successful economic stabilization took place in Estonia, followed by Lithuania and Latvia. One of the most important priorities of Estonia for the year 2010 was the fulfilment of the Maastricht criteria, and with the introduction of the Euro on 1 January 2011 Estonia joined the Eurozone. Other priorities to be mentioned are promotion of the quality of education and preparation of the independence of the energy sector (Ministry of Economic Affairs and Communications of Estonia, 2005). In Latvia, the top priorities were reducing the unemployment and promoting entrepreneurship, as well as structural reforms in the public institutions. Like Estonia, Lithuania set the following priorities: accession to the Eurozone, as well as diversification of energy suppliers (competition) and increasing the independence in the energy sector. Lithuania as the last of the Baltic States joined the Eurozone on 1 January 2015.

The following tasks have been defined to reach the aim - to analyse the structure of the national economy in each of the Baltic States; to study the key sectors of the national economies; to determine the most competitive sector in the long-term development in each of the Baltic States and to draw conclusions.

\section{Materials and Methods}

During the research, quantitative and qualitative methods were used - monographic or descriptive method, analysis and synthesis method; data statistical research methods - grouping, comparison, analysis of relative and average indicators, establishment and analysis of dynamic series. For labour market analysis, statistical data of 10 years were compared. Calculations and data processing were performed using the software Microsoft Excel. Data on the national economy sectors were retrieved from the Statistical Bureaus of each Baltic State, as well as from the national reports on the development of the national economy. To calculate the value added by each sector to the overall structure of the national economy, the authors used the data of the Central Statistical Bureau data on gross value added broken down by kinds of activities, at current prices, without separating into subsectors, but on the basis of key sectors according to the NACE classification. To calculate growth rates the authors used the data of the Central Statistical Bureau data on gross value added broken down by kinds of activities, at current prices, separating in subsectors on the basis of key sectors according to the NACE classification.

\section{Results and Discussion}

According to the statistical classification of economic activities (Eurostat, 2017), in the European Community the national economy sectors are divided 
into agriculture, forestry and fishing; mining and quarrying; electricity, gas, steam and air conditioning; water supply, sewerage, waste management and remediation, manufacturing; construction. The rest are service industries - wholesale and retail trade, repair of motor vehicles and motorcycles; transportation and storage; accommodation and food service activities; information and communication; financial and insurance activities; real estate activities; professional, scientific and technical activities; administrative and support service activities; other service activities; public administration and defence; compulsory social security; education; human health and social work activities; arts, entertainment and recreation; activities of households as employers; undifferentiated goodsand services-producing activities of households for own use; activities of extraterritorial organizations and bodies.

The development of the national economy sectors in Latvia

On the basis of the reports on the national economy by the Ministry of Economics of the Republic of Latvia for 2005 - 2015 (Ministry of Economics of the Republic of Latvia, 2005; 2015), the fastest growing economy sector is service sector,

The structure of the national economy of Latvia by value added, $2005-2015, \%$

Table 1 (designed by the authors according to the data of the Central Statistical Bureau of Latvia)

\begin{tabular}{|c|c|c|c|c|c|c|c|c|c|c|c|}
\hline \multirow{2}{*}{ Economic Activity } & \multicolumn{11}{|c|}{ Year } \\
\hline & 2005 & 2006 & 2007 & 2008 & 2009 & 2010 & 2011 & 2012 & 2013 & 2014 & 2015 \\
\hline Agriculture, Forestry and Fishing & 4.3 & 3.7 & 3.7 & 3.3 & 3.7 & 4.4 & 3.9 & 3.7 & 3.7 & 3.5 & 3.4 \\
\hline Mining and quarrying & 0.3 & 0.3 & 0.3 & 0.3 & 0.5 & 0.5 & 0.5 & 0.5 & 0.5 & 0.5 & 0.5 \\
\hline Manufacturing & 13.0 & 12.1 & 11.4 & 10.8 & 10.9 & 13.4 & 13.2 & 13.1 & 12.7 & 12.3 & 12.3 \\
\hline $\begin{array}{l}\text { Electricity, gas, steam and air } \\
\text { conditioning supply }\end{array}$ & 2.2 & 2.1 & 2.0 & 2.5 & 3.4 & 3.9 & 3.5 & 3.3 & 3.2 & 3.0 & 2.8 \\
\hline $\begin{array}{l}\text { Water supply, sewerage, waste } \\
\text { management and remediation } \\
\text { activities }\end{array}$ & 0.7 & 0.7 & 0.7 & 0.8 & 1.2 & 1.0 & 1.0 & 0.9 & 0.9 & 0.9 & 0.9 \\
\hline Construction & 6.7 & 8.5 & 10.1 & 10.1 & 7.7 & 5.0 & 5.9 & 6.4 & 6.5 & 6.7 & 6.4 \\
\hline $\begin{array}{l}\text { Wholesale and retail trade; } \\
\text { repair of motor vehicles and } \\
\text { motorcycles }\end{array}$ & 16.5 & 16.8 & 15.6 & 14.0 & 15.1 & 15.6 & 14.7 & 14.1 & 14.0 & 14.1 & 14.0 \\
\hline Transportation and storage & 12.3 & 9.8 & 8.4 & 9.3 & 10.5 & 10.5 & 10.5 & 10.5 & 10.2 & 10.1 & 9.5 \\
\hline $\begin{array}{l}\text { Accommodation and food service } \\
\text { activities }\end{array}$ & 1.5 & 1.5 & 1.6 & 1.6 & 1.6 & 1.6 & 1.7 & 1.6 & 1.7 & 1.8 & 1.9 \\
\hline Information and communication & 4.6 & 4.1 & 3.6 & 3.8 & 4.2 & 4.6 & 4.3 & 4.3 & 4.4 & 4.4 & 4.6 \\
\hline Financial and insurance activities & 4.4 & 5.2 & 5.2 & 5.6 & 3.6 & 3.4 & 4.0 & 4.1 & 4.0 & 4.5 & 4.7 \\
\hline Real estate activities & 9.5 & 11.3 & 12.3 & 11.1 & 11.2 & 10.2 & 11.0 & 11.9 & 12.6 & 13.2 & 13.3 \\
\hline $\begin{array}{l}\text { Professional, scientific and } \\
\text { technical activities }\end{array}$ & 3.8 & 3.6 & 4.1 & 4.5 & 4.6 & 4.5 & 4.6 & 4.5 & 4.4 & 4.1 & 4.2 \\
\hline $\begin{array}{l}\text { Administrative and support } \\
\text { service activities }\end{array}$ & 2.3 & 2.2 & 2.4 & 2.5 & 2.5 & 2.8 & 3.1 & 3.0 & 3.0 & 2.8 & 2.9 \\
\hline $\begin{array}{l}\text { Public administration and } \\
\text { defence; compulsory social } \\
\text { security }\end{array}$ & 7.3 & 7.9 & 8.4 & 8.5 & 7.8 & 7.5 & 7.5 & 7.3 & 7.3 & 7.3 & 7.4 \\
\hline Education & 5.0 & 4.6 & 4.6 & 5.4 & 5.9 & 5.2 & 4.9 & 4.8 & 4.9 & 4.9 & 5.0 \\
\hline $\begin{array}{l}\text { Human health and social work } \\
\text { activities }\end{array}$ & 2.8 & 2.7 & 2.6 & 3.0 & 3.2 & 3.1 & 2.9 & 2.9 & 3.0 & 3.2 & 3.3 \\
\hline $\begin{array}{l}\text { Arts, entertainment and } \\
\text { recreation }\end{array}$ & 2.0 & 2.2 & 2.1 & 2.1 & 1.7 & 1.8 & 1.9 & 1.9 & 2.0 & 2.0 & 2.1 \\
\hline Other service activities & 0.8 & 0.7 & 0.8 & 0.7 & 0.8 & 0.8 & 0.8 & 0.9 & 0.8 & 0.8 & - \\
\hline $\begin{array}{l}\text { Activities of households as } \\
\text { employers }\end{array}$ & 0.1 & 0.1 & 0.1 & 0.1 & 0.2 & 0.2 & 0.2 & 0.2 & 0.1 & 0.2 & - \\
\hline
\end{tabular}


especially commercial services. The construction sector witnessed a very rapid growth in the period from 2007 to 2008; this growth was due to the changes in the lending policy of the financial institutions. Whereas, in manufacturing there was a decline; if in 2005 the share of manufacturing in value added was $13.0 \%$, then in 2008 it was $10.8 \%$, which is lower by 2.2 percentage points (Table 1). Table 1 shows the structure of the national economy during the period from 2005 to 2015.

During the economic downturn, i.e. in 2009, a number of production companies were forced to close their activities due to the sharp decline of the purchasing power in both domestic and foreign markets.

In Latvia, manufacturing has a small share in the overall structure of the national economy, which is significantly below average in the European Union; only Cyprus, Luxembourg, the Netherlands and the UK have a smaller share of manufacturing in the national economy (in the total value added). In 2010 - 2012, manufacturing had a major role in the overall development of the national economy, but closing of the JSC 'Liepājas Metalurgs' (metallurgical company) had a significant impact on the manufacturing sector from 2013 onwards.

In addition to the analysis of the structure of the national economy, the authors carried out the analysis of the growth rates. When analysing the growth rates, the first quarter of 2007 saw the most significant increase in manufacturing as compared to the first quarter of the previous year, and it was $31.4 \%$, while in 2015 there was a downward trend in all quarter indicators in the transportation and storage sector as compared to 2014. This trend continued also in 2016. Financial and insurance activities, as well as real estate activities experienced a very sharp increase; in the first quarter of 2011 the growth in financial and insurance activities was $71.4 \%$ against the first quarter of the previous year.

Taking into consideration these three national economy sectors - manufacturing, trade and real estate activities, which during the period from 2005 to 2015 accounted for about $40 \%$ in the overall structure of the national economy, even during the economic downturn in 2008 and 2009 they continued to develop and maintain or even increase this proportion, within the framework of this research, the authors conducted a thorough analysis of the above three sectors in order to identify those sub-sectors which stimulate the overall development of the sector and the factors contributing to the development.

The share of manufacture of food products, beverages and tobacco products in manufacturing as to the value added amounted to $26.0 \%$ in 2005 , the second highest share belongs to the manufacture of wood and of products of wood and cork $-17.2 \%$, while in 2015 these shares were $23.6 \%$ and $27.0 \%$ accordingly. These two sub-sectors account for nearly $50 \%$ of total manufacturing. According to Sutcliffe \& Glyn (2003), the importance of the manufacturing sector is underestimated, considering only the value added or employment in the sector. Many other sectors are closely related to the manufacturing sector. Parts of agricultural, mining, energy, construction, transportation, and financial, as well as many other business services, are highly dependent on manufacturing results. Therefore, some of these sectors also participate in manufacturing markets. Many other sectors are involved in manufacturing processes indirectly, through integration with manufacturing products (Pekarskiene \& Susniene, 2013). It means that all Baltic state countries need to invest more in manufacturing, thereby increasing added value not only in manufacturing, but in other sectors too.

Manufacturing as a whole is significantly impacted by exporting possibilities and volumes which grew starting from 2010 onwards and decreased in 2013 due to the influence of Russia's economic deterioration and food import restrictions (Danske Bank, 2014). A steady growth has been observed in the woodworking sector, which in spite of the various national restrictions and export shrinkage, shows a significant increase. $75 \%$ of production is exported and mainly to the European Union countries. This position highlights the role of resources, which are obtainable in the particular country, and in the Latvian case, wood is the most important resource, also for international trade. Many authors, Maddison (1995), Hirst \& Thompson (2003), Feenstra (1998), Sutcliffe \& Glyn (2003), refer to international trade as one of the most important forms of integration into the global economy. If an economic sector is more globalized, the greater the portion of its output is exported (Pekarskiene \& Susniene, 2013). It means that the development of export output will always be one of the main goals to achieve, especially in the Baltic countries, because economy of these countries is relatively small comparing with other European countries.

The development of the national economy sectors in Estonia

After the collapse of the Union of Soviet Socialist Republics and regaining of independence, Estonia has been the fastest growing country among the Baltic States. Telecommunications and information technology, textiles, chemical products, wood and its products, shipbuilding, electronics, transportation, food and fishing, various services are the key sectors in the national economy of Estonia. Estonia produces 
The structure of the national economy of Estonia by value added, $2005-2015, \%$

Table 2 (designed by the authors according to the data of the Central Statistical Bureau of Estonia)

\begin{tabular}{|c|c|c|c|c|c|c|c|c|c|c|c|}
\hline \multirow{2}{*}{ Economic Activity } & \multicolumn{11}{|c|}{ Year } \\
\hline & 2005 & 2006 & 2007 & 2008 & 2009 & 2010 & 2011 & 2012 & 2013 & 2014 & 2015 \\
\hline Agriculture, forestry and fishing & 3.5 & 3.1 & 3.5 & 2.7 & 2.4 & 3.2 & 3.9 & 3.7 & 3.5 & 3.6 & 3.4 \\
\hline Mining and quarrying & 0.9 & 1.0 & 1.0 & 1.0 & 1.2 & 1.4 & 1.4 & 1.3 & 1.5 & 1.6 & 1.4 \\
\hline Manufacturing & 16.6 & 16.5 & 15.9 & 15.5 & 14.1 & 15.7 & 16.6 & 15.9 & 15.5 & 16.2 & 15.8 \\
\hline $\begin{array}{l}\text { Electricity, gas, steam and air } \\
\text { conditioning supply }\end{array}$ & 2.8 & 2.5 & 2.4 & 2.4 & 3.5 & 3.9 & 3.5 & 3.3 & 3.9 & 3.7 & 3.2 \\
\hline $\begin{array}{l}\text { Water supply; sewerage, waste } \\
\text { management and remediation } \\
\text { activities }\end{array}$ & 0.9 & 0.9 & 0.9 & 1.0 & 1.0 & 1.1 & 0.9 & 0.9 & 0.8 & 0.8 & 0.7 \\
\hline Construction & 8.6 & 9.8 & 10.6 & 9.6 & 7.1 & 5.9 & 6.9 & 7.3 & 6.9 & 6.4 & 6.2 \\
\hline $\begin{array}{l}\text { Wholesale and retail trade; } \\
\text { repair of motor vehicles and } \\
\text { motorcycles }\end{array}$ & 14.4 & 14.4 & 13.8 & 12.8 & 11.7 & 11.8 & 12.1 & 12.5 & 12.2 & 12.0 & 11.9 \\
\hline Transportation and storage & 8.5 & 8.4 & 7.8 & 7.7 & 8.0 & 9.0 & 8.8 & 8.9 & 8.9 & 8.4 & 7.8 \\
\hline $\begin{array}{l}\text { Accommodation and food service } \\
\text { activities }\end{array}$ & 1.7 & 1.7 & 1.6 & 1.7 & 1.5 & 1.5 & 1.6 & 1.7 & 1.8 & 1.8 & 1.8 \\
\hline Information and communication & 4.7 & 4.5 & 4.6 & 4.9 & 5.5 & 5.3 & 5.0 & 5.1 & 5.4 & 5.6 & 6.0 \\
\hline Financial and insurance activities & 3.9 & 4.4 & 4.7 & 5.4 & 4.4 & 4.1 & 3.9 & 3.9 & 3.6 & 3.9 & 4.0 \\
\hline Real estate activities & 9.8 & 9.7 & 9.6 & 9.7 & 10.6 & 9.8 & 9.7 & 9.8 & 9.8 & 9.8 & 10.1 \\
\hline $\begin{array}{l}\text { Professional, scientific and } \\
\text { technical activities }\end{array}$ & 4.4 & 4.4 & 4.6 & 4.9 & 5.3 & 5.3 & 5.0 & 4.9 & 4.9 & 5.0 & 5.3 \\
\hline $\begin{array}{l}\text { Administrative and support } \\
\text { service activities }\end{array}$ & 3.3 & 3.5 & 3.4 & 3.5 & 3.8 & 3.7 & 3.8 & 4.0 & 4.1 & 3.6 & 3.8 \\
\hline $\begin{array}{l}\text { Public administration and } \\
\text { defence; compulsory social } \\
\text { security }\end{array}$ & 5.7 & 5.4 & 5.7 & 6.6 & 8.0 & 7.5 & 6.8 & 6.6 & 6.7 & 6.9 & 7.3 \\
\hline Education & 4.6 & 4.3 & 4.2 & 4.8 & 5.5 & 5.0 & 4.5 & 4.4 & 4.5 & 4.6 & 4.7 \\
\hline $\begin{array}{l}\text { Human health and social work } \\
\text { activities }\end{array}$ & 3.1 & 3.0 & 3.1 & 3.4 & 3.9 & 3.7 & 3.4 & 3.4 & 3.5 & 3.7 & 4.0 \\
\hline $\begin{array}{l}\text { Arts, entertainment and } \\
\text { recreation }\end{array}$ & 1.8 & 1.8 & 1.8 & 1.5 & 1.4 & 1.3 & 1.3 & 1.4 & 1.5 & 1.5 & 1.6 \\
\hline Other service activities & 1.0 & 0.9 & 0.8 & 0.9 & 1.0 & 0.9 & 0.9 & 0.9 & 1.0 & 1.0 & 1.0 \\
\hline
\end{tabular}

$90 \%$ of the electricity needed in the country, and uses wood, peat and biomass as alternative sources of energy (Ministry of Economic Affairs and Communications of Estonia, 2005; 2015). The information gathered in Table 2 shows how the structure of the national economy of Estonia has changed during the ten-year period.

In 2005 , the highest share in the structure of the national economy belongs to the manufacturing sector, but during these 10 years the proportion of manufacturing tends to be decreasing. Trade is in the second place with exactly the same downward trend, real estate activities are in the third place - with a growing tendency in the overall structure of the national economy (Table 2).
When analysing the sub-sectors of manufacturing in more detail (Figure 1), the manufacture of wood and paper products and printing made up to $19.5 \%$ of the manufacturing sector in 2005 and $21.8 \%$ in 2015 , thus taking the first position in the manufacturing sector in the overall structure of the national economy. The second major share belongs to the manufacture of food products, beverages and tobacco products, and manufacture of basic metals and fabricated metal products is in the third place. The manufacture of basic metals and fabricated metal products has gradually increased its share in the overall structure of the manufacturing sector - from $9.6 \%$ in 2005 to $12.6 \%$ in 2015 

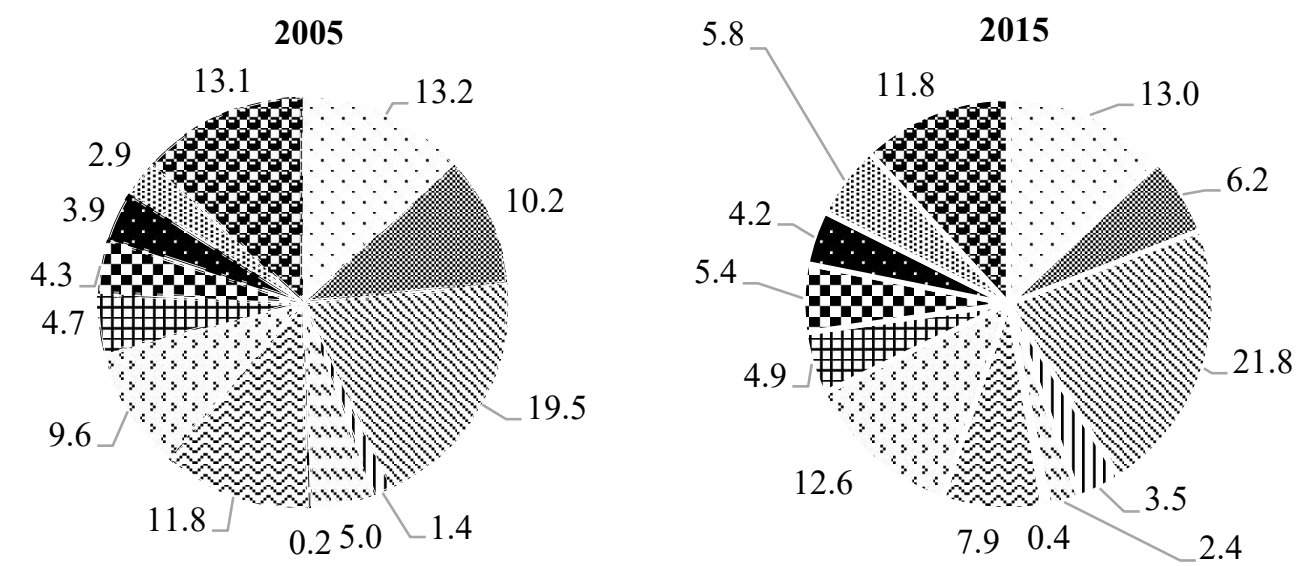

manufacture of food products, beverages and tobacco proaucts

x manufacture of textiles, wearing apparel and leather products

s manufacture of wood and paper products, and printing

I manufacture of coke and refined petroleum products

manufacture of chemicals and chemical products

manufacture of basic pharmaceutical products and pharmaceutical preparations

$\checkmark$ manufacture of rubber and plastic products, and other non-metallic mineral products

manufacture of basic metals and fabricated metal products

† manufacture of computer, electronic and optical products

manufacture of electrical equipment

manufacture of machinery and equipment n.e.c.

manufacture of transport equipment

s manufacture of furniture; other manufacturing; repair and installation of machinery and equipment

Figure 1. The structure of manufacturing in Estonia in 2005 and 2015, \%.

(designed by the authors according to the data of the Central Statistical Bureau of Estonia)

Manufacturing, trade and real estate activities account for almost $40 \%$ in the overall structure of the national economy. Figure 1 illustrates the structure of manufacturing.

In this sector more than 1,000 companies operate exporting their products mainly to Sweden, Finland and Latvia. Estonia has around 6,000 manufacturing companies; one in five workers is employed in manufacturing. The share of manufacturing in the overall structure of the national economy is higher than average in the European Union (Ministry of Economic Affairs and Communications of Estonia, 2005; 2015).

During these ten years, large amounts of investment from countries such as Finland and Sweden have flowed into Estonia; these investments are essential for the national economy of Estonia. Therefore, the manufacture of basic metals and fabricated metal products has increased its share and competitiveness in the overall structure of the national economy (Ministry of Economic Affairs and Communications of Estonia, 2005; 2015).

The development of the national economy sectors in Lithuania

More than $50 \%$ of the overall structure of the national economy in Lithuania consists of manufacturing, trade and transportation and storage.
In addition, it should be noted that all these industries very gradually but with each year are increasing their share in the overall structure of the national economy, see Table 3 (Ministry of Economy of the Republic of Lithuania, 2002; 2012; Bank of Lithuania, 2002; 2012).

In Lithuania, the share of manufacturing is above average in the European Union, while the transportation and storage sector has significantly increased its share from $9.0 \%$ in 2002 to $13.0 \%$ in 2012. When analysing the structure of the national economy of Lithuania, particular attention was paid to the transportation and storage sector, as this sector in Lithuania, and the European Union as a whole, plays a significant role because it is growing faster than average in the European Union; and also the volumes of exported production in this sector are higher than average in the European Union (Langviniene \& Sliziene, 2014). On the whole, the development of this sector is unstable, because it is affected by global processes, such as one-third of the total production is exported to the CIS countries, and these countries, mainly Russia, are introducing various obstacles for the European Union countries (transport documentation, volumes, etc.).

When analysing manufacturing in more detail, $60 \%$ of it consists of manufacture of food products, beverages and tobacco products $(22.4 \%$ in 2002 and 
The structure of the national economy of Lithuania by value added, $2002-2012, \%$. (designed by the authors according to the data of the Central Statistical Bureau of Lithuania)

\begin{tabular}{|c|c|c|c|c|c|c|c|c|c|c|c|}
\hline \multirow{2}{*}{ Economic Activity } & \multicolumn{11}{|c|}{ Year } \\
\hline & 2002 & 2003 & 2004 & 2005 & 2006 & 2007 & 2008 & 2009 & 2010 & 2011 & 2012 \\
\hline Agriculture, forestry and fishing & 5.4 & 5.0 & 4.6 & 4.8 & 4.2 & 3.9 & 3.7 & 2.8 & 3.3 & 3.8 & 4.0 \\
\hline Mining and quarrying & 0.6 & 0.6 & 0.5 & 0.5 & 0.5 & 0.5 & 0.4 & 0.3 & 0.4 & 0.4 & 0.4 \\
\hline Manufacturing & 18.3 & 18.6 & 20.0 & 20.1 & 19.4 & 17.8 & 17.5 & 16.8 & 18.9 & 20.5 & 20.8 \\
\hline $\begin{array}{l}\text { Electricity, gas, steam and air } \\
\text { conditioning supply }\end{array}$ & 3.5 & 4.2 & 4.0 & 3.6 & 3.2 & 3.0 & 2.8 & 3.4 & 3.3 & 2.8 & 2.9 \\
\hline $\begin{array}{l}\text { Water supply; sewerage, waste } \\
\text { management and remediation } \\
\text { activities }\end{array}$ & 0.8 & 0.8 & 0.8 & 0.7 & 0.7 & 0.7 & 0.7 & 0.8 & 0.9 & 1.0 & 1.0 \\
\hline Construction & 6.3 & 7.0 & 7.2 & 7.8 & 9.4 & 11.2 & 11.2 & 6.6 & 5.9 & 6.5 & 6.0 \\
\hline $\begin{array}{l}\text { Wholesale and retail trade; } \\
\text { repair of motor vehicles and } \\
\text { motorcycles }\end{array}$ & 17.7 & 17.5 & 17.7 & 17.5 & 17.0 & 16.9 & 17.4 & 17.6 & 17.9 & 17.9 & 18.6 \\
\hline Transportation and storage & 9.0 & 9.3 & 9.2 & 9.5 & 9.8 & 9.9 & 9.4 & 10.7 & 12.0 & 12.2 & 13.0 \\
\hline $\begin{array}{l}\text { Accommodation and food service } \\
\text { activities }\end{array}$ & 1.6 & 1.5 & 1.5 & 1.4 & 1.3 & 1.3 & 1.3 & 1.4 & 1.3 & 1.3 & 1.3 \\
\hline Information and communication & 5.1 & 5.0 & 4.4 & 4.1 & 3.9 & 3.7 & 3.4 & 3.9 & 3.6 & 3.1 & 3.1 \\
\hline Financial and insurance activities & 2.1 & 1.7 & 1.7 & 2.2 & 2.7 & 3.3 & 3.3 & 2.2 & 2.6 & 2.7 & 2.2 \\
\hline Real estate activities & 6.5 & 6.2 & 6.2 & 6.4 & 6.5 & 6.5 & 6.9 & 7.3 & 6.6 & 6.0 & 5.7 \\
\hline $\begin{array}{l}\text { Professional, scientific and } \\
\text { technical activities }\end{array}$ & 2.6 & 3.3 & 3.3 & 3.4 & 3.5 & 3.9 & 3.6 & 4.1 & 3.7 & 3.6 & 3.4 \\
\hline $\begin{array}{l}\text { Administrative and support } \\
\text { service activities }\end{array}$ & 1.4 & 1.4 & 1.5 & 1.7 & 1.8 & 2.0 & 2.1 & 2.3 & 2.1 & 2.0 & 2.2 \\
\hline $\begin{array}{l}\text { Public administration and } \\
\text { defence; compulsory social } \\
\text { security }\end{array}$ & 7.9 & 7.7 & 7.4 & 6.9 & 6.9 & 6.4 & 6.6 & 7.4 & 6.7 & 6.2 & 5.8 \\
\hline Education & 5.7 & 5.2 & 5.0 & 4.5 & 4.4 & 4.2 & 4.7 & 6.1 & 5.3 & 4.8 & 4.5 \\
\hline $\begin{array}{l}\text { Human health and social work } \\
\text { activities }\end{array}$ & 2.9 & 2.7 & 2.7 & 2.7 & 2.9 & 3.0 & 3.3 & 4.0 & 3.6 & 3.5 & 3.4 \\
\hline $\begin{array}{l}\text { Arts, entertainment and } \\
\text { recreation }\end{array}$ & 0.8 & 0.7 & 0.8 & 1.0 & 0.9 & 0.9 & 0.8 & 1.0 & 0.9 & 0.9 & 0.9 \\
\hline Other service activities & 1.7 & 1.6 & 1.4 & 1.1 & 0.9 & 0.8 & 0.8 & 1.0 & 0.9 & 0.8 & 0.8 \\
\hline $\begin{array}{l}\text { Activities of households as } \\
\text { employers }\end{array}$ & 0.1 & 0.1 & 0.1 & 0.2 & 0.1 & 0.1 & 0.1 & 0.1 & 0.1 & 0.1 & 0.1 \\
\hline
\end{tabular}

$24.9 \%$ in 2012), manufacture of furniture, jewellery, musical instruments, toys; repair and installation of machinery and equipment $(12.2 \%$ in 2002 and $15.7 \%$ in 2012), manufacture of chemicals and chemical products $(6.2 \%$ in 2002 and $12.5 \%$ in 2012), as well as manufacture of wood, paper, printing and reproduction (13.3\% in 2005 and $11.5 \%$ in 2012). In Lithuania, in several sectors a clear tendency to expand opportunities in the local market are observed, as in recent years there has been stagnation of exports due to the Russia's economic crisis and the restrictions set on imports; therefore new possibilities are created to realize the products internally, thus compensating for lack of export opportunities, and new markets are searched.

In Lithuania there are very many businesses working in wood processing but they are small and this hinders rapid development of the sector. In addition, these companies lack process automation. Thus, it is impossible to manufacture products in large quantities and in a short time, as in other countries where this sector is growing faster (Finland, Sweden). The food sector still accounts for the largest share of the national economy in Lithuania, in recent years this has been highest among all the Baltic States. Lithuanian food products are mostly exported, since 
the internal market is small. The export partners are Latvia, Estonia, Germany and Poland, as well as Russia, which in the future is considered to be one of the largest export partners in this sector.

Upon analysis of the results of the research, the authors believe that in the period from 2005 to 2015 , the national economy sectors of the Baltic States have evolved gradually, with the exception of the global financial crisis period in 2008 and 2009. The dynamics of the growth rate in 2014 and 2015 in comparison with the previous years has been relatively slow, but positive.

The most competitive sectors in the long-term development in each of the Baltic States are the service sector (real estate activities, financial activities, transportation and storage) and manufacturing (manufacture of wood and products of wood and cork, manufacture of food products, beverages and tobacco products).

\section{Conclusions}

1. The largest share in the overall structure of the national economy belongs to manufacturing in Latvia (from 13\% in 2005 to $12.3 \%$ in 2015), Estonia (from $16.6 \%$ in 2005 to $15.8 \%$ in 2015 ) and Lithuania (18.3\% in 2002 to $20.8 \%$ in 2012 ).

2. Approximately $40 \%$ of the overall structure of the national economy in each Baltic State consists of three sectors (in Latvia - manufacturing, trade and real estate activities, in Lithuania - manufacturing, trade and transportation and storage, in Estonia - manufacturing, trade and real estate activities). In manufacturing, in Latvia the greatest value is added by manufacture of food products, beverages and tobacco products and manufacture of wood and of products of wood and cork (in 2015 accounting for more than $50 \%$ ), in Lithuania manufacture of food products, beverages and tobacco products, manufacture of chemicals and chemical products, manufacture of furniture (in 2012 accounting for more than 50\%), in Estonia - manufacture of food products, beverages and tobacco products; manufacture of wood and of products of wood and cork; manufacture of basic metals and fabricated metal products (in 2015 accounting for approximately 50\%).

3. As a result of the analysis, the sector that is the most competitive and significantly affecting the structure of the national economy in each Baltic State has been identified. In Lithuania it is transportation and storage, in Estonia and Latvia the manufacture of wood and of products of wood and cork.

4. Manufacturing has been underestimated in the overall structure of the national economy, since virtually all other national economy sectors depend on the development of the manufacturing sector.

5. The economic development and output volumes of each Baltic State are related to global developments, the relations between the European Union and other countries, especially Russia and the former CIS countries.

\section{References}

1. Bank of Lithuania (2002). Annual report of the Bank of Lithuania. Vilnius: Bank of Lithuania.

2. Bank of Lithuania (2012). Annual report of the Bank of Lithuania. Vilnius: Bank of Lithuania.

3. Central Statistical Bureau of Latvia (2017). Total gross value added by kind of activity. Retrieved January 8, 2017, from: http://www.csb.gov.lv/en/dati/statistics-database-30501.html.

4. Central Statistical Bureau of Latvia (2017). Gross domestic product by kind of activity. Retrieved January 10, 2017, from: http://www.csb.gov.lv/en/dati/statistics-database-30501.html.

5. Danske Bank (2014). Baltic economies. Vilnius: Danske Bank A/S Lithuania branch.

6. Eurostat (2017). Statistical classification of economic activities in the European Community (NACE). Retrieved February 2, 2017, from: http://ec.europa.eu/eurostat/statistics-explained/index.php/Main_Page.

7. Feenstra, R. (1998). Integration of trade and disintegration of production in the global economy. Journal of Economic Perspectives. 12(4), 31 - 50. DOI: 10.1257/jep.12.4.31.

8. Hirst, P., \& Thompson, G. (2003). The future of globalisation. In J. Michie (Ed.), The Handbook of Globalisation. Cheltenham: Edward Elgar Publishing Limited.

9. Langvinienè, N., \& Sližienè, G. (2014). Changes for the Transport and Logistics Services Business: The Case of Lithuania. Economics and Business. 26, 61 - 68. DOI: 10.7250/eb.2014.021.

10. Maddison, A. (1995). Monitoring the world economy, 1820 - 1992. Paris: OECD Development Centre.

11. Ministry of Economic Affairs and Communications of Estonia, Ministry of Finance of Estonia (2005). Overview of economy. Tallinn: Ministry of Economic Affairs and Communications of Estonia. Ministry of Finance of Estonia.

12. Ministry of Economic Affairs and Communications of Estonia, Ministry of Finance of Estonia (2015). Overview of economy. Tallinn: Ministry of Economic Affairs and Communications of Estonia. Ministry of Finance of Estonia. 
13. Ministry of Economics of the Republic of Latvia (2005). Report on the Economic Development of Latvia. Riga: Ministry of Economics of the Republic of Latvia.

14. Ministry of Economics of the Republic of Latvia (2015). Report on the Economic Development of Latvia. Riga: Ministry of Economics of the Republic of Latvia.

15. Ministry of Economy of the Republic of Lithuania (2002). Economy review on Lithuania. Vilnius: Ministry of Economy of the Republic of Lithuania.

16. Ministry of Economy of the Republic of Lithuania (2012). Economy review on Lithuania. Vilnius: Ministry of Economy of the Republic of Lithuania.

17. Pekarskiene, I., \& Susniene, R. (2013). Features of the Lithuanian manufacturing industry development in the context of globalization. Economics and Management. 18 (4), 684 - 696. DOI: 10.5755/j01. em.18.4.5846.

18. Statistics Estonia (2017). Value added by economic activity. Retrieved January 12, 2017, from: http://www. stat.ee/?lang=en.

19. Statistics Lithuania (2017). Gross value added and gross domestic product by production approach by economic activity. Retrieved January 14, 2017, from: http://www.stat.gov.lt/lt/.

20. Sutcliffe, B., \& Glyn, A. (2003). Measures of globalisation and their misinterpretation. In J. Michie (Ed.). The Handbook of Globalisation. Cheltenham: Edward Elgar Publishing Limited. 